The Ideology of the Offensive 
A volume in the series

\section{Cornell Studies in Security Affairs}

edited by ROBERT JERVIS,

ROBERT J. ART

STEPHEN M. WALT

A full list of titles in the series appears at the end of the book. 


\title{
The Ideology of the Offensive
} MILITARY DECISION MAKING AND THE DISASTERS OF 1914

\author{
JACK SNYDER
}

Cornell University Press

ITHACA AND LONDON 


\section{Copyright $\odot 1984$ by Cornell University}

All rights reserved. Except for brief quotations in a review, this book, or parts thereof, must not be reproduced in any form without permission in writing from the publisher. For information address Cornell University Press,

Sage House, 512 East State Street, Ithaca, New York 14850.

First published 1984 by Cornell University Press First printing, Comell Paperbacks, 1989 ISBN: 978-0-8014-8244-1

International Standard Book Number 0-8014-1657-4 (cloth) International Standard Book Number o-8014-9584-4 (paper) Library of Congress Catalog Card Number $84-7783$

Printed in the United States of America

Librarians: Library of Congress cataloging information appears on the last page of the book.

Cornell University Press strives to use environmentally responsible suppliers and materials to the fullest extent possible in the publishing of its books. Such materials include vegetable-based, low-VOC inks and acid-free papers that are recycled, totally chlorine-free, or partly composed of nonwood fibers.

$\begin{array}{lllllllllll}1 & 2 & 3 & 4 & 5 & 6 & 7 & 8 & 9 & 10 & \text { Cloth printing }\end{array}$
$\begin{array}{lllllllll}3 & 4 & 5 & 6 & 7 & 8 & 9 & 10 & \text { Paperback printing }\end{array}$ 